\title{
THE EFFECT OF COMPLEX TRAINING ON THE EXPLOSIVE STRENGTH OF THE FEET OF FOOTBALL PLAYERS AGES (17-19) YEARS
}

\author{
Haider Abdul badan AlMayahi, Prof.Dr. Abbas Ali eadhab \\ University of Baghdad / College of Physical Education and Sports Sciences
}

DOI: $10.37648 /$ ijrssh.v10i02.038

Received: 20 $0^{\text {th }}$ March, 2020; Accepted: $24^{\text {th }}$ April, 2020; Published: $13^{\text {th }}$ May, 2020

\begin{abstract}
Football is the first popular game in the world, which has evolved clearly and significantly in recent years, and the need to improve physical, skill and planning performance is necessary to reach the player to a high and elaborate performance in any circumstances of the match, so there are numerous methods and methods of sports training, Complex training is one of the modern training methods. and The objectives of the study

.The preparation of complex exercises in football players -

- Knowing the effect of these exercises on the explosive strength of the feet in soccer players and The researchers concluded that more complex training has an effect on the development of the (explosive strength of the two legs) than conventional exercises.
\end{abstract}

\section{INTRODUCTION}

The world is witnessing significant and continuous development in various scientific, economic and social fields, and the sports field is one of the important life areas, which depends largely on the achievement that the player accomplishes in various activities. Sports events. This development can be observed through the multiplicity and diversity of methods and methods of sports training based on The correct scientific foundations, clearly, through breaking records and the constant change of the laws of play, and football is the first popular game in the world, which has evolved clearly and significantly in recent years, and that the need to improve DONC physical skill and tactical is necessary to get the player to the performance of highly elaborate and in any circumstances of the game conditions, so there were many ways and methods of sports training, and is a training complex is a modern training methods.

Intended training is complex training that combines traditional resistance training with heavyweights with jumping exercises, which is (traditional squat training followed by squat training with jumping) or chest training (Bing Press) followed by throwing heavyweights, since the logical analysis of this type of training is that resistance training stimulates the device The nervous system and causes it to work at its maximum energy, causing high stimulation of the fastcontracting muscle fibers type (2B), which is the main factor when conducting jumping exercises.

That the explosive force is an important physical ability in the game of poke the foot "and means the highest 
dynamic force that a muscle or muscle group can produce once, as in some scientific references they do not differentiate between the ability (the explosive force) and the ability (the force characterized by speed), meaning that the two capabilities are It is a force $\mathrm{x}$ velocity, but the explosive force appears through what is characterized by the highest strength and the highest possible speed for once, and thus it is the maximum instantaneous rapid force."

Hence the importance of the research, which aims to develop the explosive power of the two men for soccer players.

As for the problem of the study, it is through the researchers' knowledge of most of the championships in the Iraqi league and of different grades and age groups, in addition to knowing all that is new in the science of training, and other auxiliary sciences used by many countries of the world that have caused a major development in the game of football, it was found that Some developed countries in football have used complex training method, which led the researcher to research in studying this problem, by preparing complex training method and knowing the effect of this method on explosive role models.

Objectives of the study.

.The preparation of complex exercises in football players

Knowing the effect of these exercises on the explosive strength of the feet in soccer players.
Research hypotheses:

- There are statistically significant differences between the pre and post tests and the experimental and control groups in the explosive strength of the two men for football players and for the benefit of dimensional tests.

- There are statistically significant differences between the results of the dimensional tests of the experimental and control groups in the explosive strength of the football players and in favor of the experimental group.

\section{MATERIALS AND METHODS:}

The researchers adopted the experimental approach with the two control and experimental groups with pre and post tests for its suitability to solve the research problem, the research community was deliberately chosen and who represent (10) clubs and the number of players in it (200 players) from the youth category, while the sample of the research represented by Al-Kazimiya Sports Club and its number (20) The research player was randomly chosen, thus the sample rate represents $10 \%$ of the original community, knowing that the research sample was also randomly divided into two experimental and control groups, by lottery (10) players for each group, then the researchers conducted a homogeneity Sample search in variables Under consideration (explosive force) as shown in Table 1 .

Table (1)

It shows the homogeneity of the research sample in the variables under study

\begin{tabular}{|l||l||l||l|l||l||}
\hline $\begin{array}{l}\text { Coefficient of } \\
\text { torsion }\end{array}$ & $\begin{array}{l}\text { standard } \\
\text { deviation }\end{array}$ & Mediator & $\begin{array}{l}\text { Arithmetic } \\
\text { mean }\end{array}$ & $\begin{array}{l}\text { measruing } \\
\text { unit }\end{array}$ & Variables \\
\hline \hline 0.319 & 4.204 & 41.100 & 41.100 & $\mathrm{~cm}$ & $\begin{array}{l}\text { The explosive strength of } \\
\text { the feet }\end{array}$ \\
\hline
\end{tabular}

$\mathrm{N}=20$

The researchers also calculated the equivalence by testing ( $t$ ) for the independent samples, and Table (2) shows the equivalence of the sample due to the presence of random differences in the explosive strength of the feet.

Table (2)

The arithmetic mean, standard deviations, calculated value (t), error level, and significance of the differences between the two research groups in the two tests show the explosive strength

\begin{tabular}{|c|c|c|c|c|c|c|c|c|}
\hline \multirow[t]{2}{*}{ indication } & \multirow{2}{*}{$\begin{array}{l}\text { Error } \\
\text { level }\end{array}$} & \multirow{2}{*}{$\begin{array}{l}\text { Computed } t \\
\text { value }\end{array}$} & \multicolumn{2}{|c|}{ Experimental group } & \multicolumn{2}{|c|}{ Control group } & \multirow{2}{*}{$\begin{array}{l}\text { measruing } \\
\text { unit }\end{array}$} & \multirow[t]{2}{*}{ Variables } \\
\hline & & & $\begin{array}{l}\text { standard } \\
\text { deviation }\end{array}$ & $\begin{array}{l}\text { Arithmetic } \\
\text { mean }\end{array}$ & $\begin{array}{l}\text { standard } \\
\text { deviation }\end{array}$ & $\begin{array}{l}\text { Arithmetic } \\
\text { mean }\end{array}$ & & \\
\hline random & 0.252 & 1.182 & 3.972 & 40.000 & 4.341 & 42.200 & $\mathrm{~cm}$ & $\begin{array}{l}\text { The explosive strength } \\
\text { of the feet }\end{array}$ \\
\hline
\end{tabular}


Degree of freedom $(10+10-2=18)$

Moral at the error level (0.05) if the error level is smaller than $(0.05)$

The two researchers measured the explosive strength of the two men through a test of vertical jump from stability.

Testing the explosive strength of the lower limbs:

Test name: (vertical jump from stability)

The purpose of the test: to measure the explosive strength of the two men

Instruments and tools used for measurement: (metallic tape, suitable wall height, chalk, recorder, registration form).

Performance description: The player stands facing against the wall with the shoulder of the arm holding the piece of chalk, which he raises high along the entire stretch to make a mark on the wall at the maximum point you reach, then bends the knees, and the weight of the arms in front high with the knees extended to jump up to make another mark at the maximum point you reach Hand in while jumping.

Note: The heels should not be lifted from the ground when making the first sign.

Recording: the distance between the first mark (from standing) and the second score (from jumping) is calculated and the player is given three attempts to score for him the best.

The reconnaissance experiment was conducted on Friday morning (10:30), coincident (19/4/2019), on (4) players from the research sample who were excluded when conducting the main experiment in the Al-Kadhimiya
Sports Club stadium, to find out the most important obstacles and negatives that may occur during The test is to avoid these obstacles when conducting pre- and posttests on the research sample.

The researchers conducted the pre-test on the morning of Saturday, April 20, 2019, and on the Al-Kadhimiya Club Stadium, in order to implement the test (vertical jump from stability) at exactly 10:30 am.

As for the main experiment, the researchers applied their complex training by (24) training units distributed by (3) units per week, which included Sunday, Tuesday and Thursday, and for a period of (8) weeks, as the training began on Tuesday, April 23, 2019. Al-Kadhimiya Sports Club stadium, as the duration of these exercises lasted between (45-55) minutes within the main unit of the training unit and during the special preparation period, and the researchers adopted the intensity from (75- to the intensity of $100 \%$ ), taking into account determining the rest periods between each repetition And the last rest between groups and the training ended on Sunday $(16 / 6 / 2019)$.

After completing the implementation of the complex exercises and within the specified period, the researchers conducted the post-test on the morning of Wednesday, $19 / 19 / 2019$ at 10:30, as the researchers were keen, as possible, in creating and controlling conditions similar to the pre-test (in terms of location) And the way to implement the tests), and the researchers used the appropriate statistical means through the statistical bag (SPSS).

\section{RESULT AND DISCUSSION:}

Table (3) shows a difference

Arithmetic media, standard deviation, calculated value (t), and significance of the differences between the results of the pre and post tests in the test the explosive strength of the feet of the control group

\begin{tabular}{|l||l||l||l||l||l||l||}
\hline $\begin{array}{l}\text { Indication of } \\
\text { differences }\end{array}$ & Error level & $\begin{array}{l}\text { Computed } \mathrm{t} \\
\text { value }\end{array}$ & $\mathrm{PF}$ & $\mathrm{P}$ & $\begin{array}{l}\text { measruing } \\
\text { unit }\end{array}$ & Variables \\
\hline random & 0.339 & 0.885 & 1.429 & 0.400 & $\mathrm{~cm}$ & $\begin{array}{l}\text { The explosive strength } \\
\text { of the feet }\end{array}$ \\
\hline
\end{tabular}

Degree of freedom $(10-1=9) .462$

Moral at the error level (0.05) if the error level is smaller than $(0.05)$ 
Table (4) shows a difference

Arithmetic media, standard deviation, calculated value ( $\mathrm{t}$ ), and indication of differences between the results of the pre and post tests in the test The explosive strength of the feet of the experimental group

\begin{tabular}{|c|c|c|c|c|c|c|}
\hline $\begin{array}{l}\text { Indication } \\
\text { differences }\end{array}$ & $\begin{array}{l}\text { Error } \\
\text { level }\end{array}$ & $\begin{array}{ll}\text { Computed } & t \\
\text { value } & \end{array}$ & $\mathrm{PF}$ & $\mathrm{P}$ & measruing unit & Variables \\
\hline moral & 0.000 & 7,727 & 3.315 & 8.100 & $\mathrm{~cm}$ & $\begin{array}{l}\text { The explosive strength } \\
\text { of the feet }\end{array}$ \\
\hline
\end{tabular}

Degree of freedom $(10-1=9)$

) Moral at the error level (0.05) if the error level is less than $(0.05$

Table (5)

The arithmetic mean, standard deviations, calculated value (t), error level, and significance of differences between the two research groups in the test show the explosive strength of the feet in the post test

\begin{tabular}{|c|c|c|c|c|c|c|c|c|}
\hline \multirow[t]{2}{*}{ indication } & \multirow{2}{*}{$\begin{array}{l}\text { Error } \\
\text { level }\end{array}$} & \multirow{2}{*}{$\begin{array}{l}\text { Computed } \mathrm{t} \\
\text { value }\end{array}$} & \multicolumn{2}{|c|}{ Experimental group } & \multicolumn{2}{|c|}{ Control group } & \multirow{2}{*}{$\begin{array}{l}\text { measruing } \\
\text { unit }\end{array}$} & \multirow[t]{2}{*}{ Variables } \\
\hline & & & $\begin{array}{l}\text { standard } \\
\text { deviation }\end{array}$ & $\begin{array}{l}\text { Arithmetic } \\
\text { mean }\end{array}$ & $\begin{array}{l}\text { standard } \\
\text { deviation }\end{array}$ & $\begin{array}{l}\text { Arithmetic } \\
\text { mean }\end{array}$ & & \\
\hline moral & 0.029 & 2.373 & 5.486 & 48.100 & 4.858 & 42.600 & $\mathrm{~cm}$ & $\begin{array}{l}\text { The explosive strength of } \\
\text { the feet }\end{array}$ \\
\hline
\end{tabular}

Degree of freedom $(10+10-2=18)$

Moral at the error level (0.05) if the error level is less than (0.05)

Through the previous tables (2, 3 and 4$)$ it is evident that there is an improvement and improvement among the individuals of the control and experimental groups sample, in the explosive force test for the two men, by noting the moral differences between the pre and post tests and in favor of the post-tests of the control and experimental groups, because the two studies attribute this development in The explosive power of the two men to the exercises that were used during the training periods as the experimental group used the complex exercises that were prepared by the researchers during the training, while the control group used the traditional exercises during the training.

As for observing Table No. (5), it becomes evident that there is an improvement and improvement of the explosive strength of the two men of the experimental group more than the control group through the moral differences between the experimental and control groups and in favor of the experimental group in the dimensional tests, so the researchers attribute that the experimental group exceeds the control group, in Posttests to the complex exercises prepared by the researchers, which were characterized by a gradual intensity during the training units (75-100\%), taking into account the rest periods between repetitions and rest between groups and ripples of the training units during the week.

\section{CONCLUSIONS:}

The researchers concluded that more complex training has an effect on the development of the (explosive strength of the two legs) than conventional exercises.

\section{REFERENCES:}

- Ahmad Abdullah Shehadeh, Weightlifting Sport, First Edition, Amman, Arab Community Library, 2013, p. 97.

- Bastawisi Ahmed: Fundamentals and theories of sports training, Cairo, Dar Al-Fikr Al-Arabi, 1999, p. 116.

- Abu Al-Alaa Abd Al-Fattah and Mohamed Sobhi Hassanein, Physiology and Morphology of Mathematics and Methods of Measurement and Evaluation: Dar Al-Fikr Al-Arabi, Cairo, 1997, p. 220. 